\title{
A ROMA TANULÓK ISKOLAI SIKERESSÉGÉNEK KÉRDÉSEI
}

\section{ASPECTS OF ROMA PUPILS' SUCCESS IN SCHOOL}

\author{
K. Nagy Emese \\ Dr. habil., egyetemi docens \\ Hejőkeresztứri IV. Béla Általános Iskola, intézményvezető, Eszterházy Károly Egyetem Pedagógiai Kar, dékán \\ k.nagy.emese@gmail.com
}

\begin{abstract}
ÖSSZEFOGLALÁS
Többen úgy vélik, hogy a tudásban és szocializáltságban megmutatkozó tanulói sokszínűség előnyt jelent mind az új információk könnyebb befogadásában, mind a szociális viselkedés pozitív irányba történő elmozdításában. Írásunk célja annak feltárása, hogy a hazai oktatás milyen lehetőségeket nyújt, illetve nyújt-e lehetőséget a hátrányos helyzetű, elsősorban roma tanulók számára, iskolai sikerességük ilyen segítséggel történő megalapozására. Írásunk arra a kérdésre is kitér, hogy a ma Magyarországon közel 150 iskola által ismert és alkalmazott Komplex Instrukciós Program miért alkalmas a roma gyerekek teljesítményének a növelésére.
\end{abstract}

\section{ABSTRACT}

It is believed that knowledge and social diversity of students are advantages in facilitating the absorption of new information, and moving their social behavior in a positive direction. The aim of our paper is to explore whether the Hungarian education system offers opportunities for the disadvantaged, mainly Roma students to establish their school success. A further point of discussion in this paper is what options the Complex Instruction Program offers in teaching and treating low-performance students.

Kulcsszavak: oktatás, iskola, hátrányos helyzetű gyerekek, roma tanulók, eredményesség, komplex instrukciós program

Keywords: education, school, disadvantage children, Roma pupils, efficiency, complex instruction program 


\section{A HAZAI OKTATÁS JELLEMZŐI}

Hazánkban a rendszerváltás óta végbement társadalmi, gazdasági és politikai változások következtében radikálisan átalakult a társadalom struktúrája, a megnőtt társadalmi egyenlőtlenségek hatása pedig az oktatás minden területén érezhető. A magyar iskolarendszer kiszolgálja az alapvető társadalmi struktúrát, teljes apparátusával, kiegészítő rendszerével, belső tartalmával, pedagógiai kultúrájával, finanszírozásával pontosan leképezi azt. Mondhatnánk, hogy ez természetes, de hozzá kell tenni, hogy a fejlett társadalmakban ez nem szükségszerü. Ezen országok iskolarendszerei nem képezik le a hazaihoz hasonló mértékben a társadalmi egyenlőtlenségeket. A fejlett országok felismerték, hogy alapvető különbséget kell tenni a képességek felhasználására épülő társadalmi mozgások (termelés, egész müködés) és a képességek termelésére vonatkozó társadalmi alaprendszerek között, amely felismerés lehetővé teszi, hogy olyan társadalompolitika müködjön, amely e tekintetben nem hajlandó ugyanazokat az esélyegyenlötlenségeket mechanikusan elfogadni az iskolázásban, tudástermelésben, mint amelyek a társadalomban létrejöttek.

Magyarországon nincs egységes iskolarendszer. A rendszerváltás után új iskolatípusok jelentek meg a hat és nyolc évfolyamos közép-, illetve egyházi iskolák létrejöttével, valamint a szakosodással és a szakképzés átalakulásával. A kitüzött oktatási célokkal szemben ezeknek az iskolatípusoknak a megjelenése azonban az egységesítéssel ellentétes hatást váltott ki, hiszen ,az egyenlötlenségek csökkenéséhez nem a választék növelése, hanem a kapacitások bővítése vezet" (Kozma, 1998). Oktatásunk jellemzője, hogy az iskolarendszer szelektív és bizonyos rétegek számára diszkriminatív jellegü működése egyrészről lehetővé teszi az elithez tartozó gyerekek továbbtanulását, másrész viszont tudatlanságot, leszakadást termel. Az elitképzés minden tényezője a teljesítmények fokozására irányul, míg az ellentéte a teljesítmények csökkenéséhez, a teljesítmény visszatartásához, és ennek következtében a lehetséges teljesítőképesség csökkenéséhez vezet. Emiatt arra kell törekedni, hogy az iskolába kerülés ne váljon egy olyan kontraszelekció eredményévé, ahol egyes társadalmi rétegek, csoportok elkerülhetetlenül hátrányba szorulnak, tanulásban lemaradnak. Az iskola egyik fontos feladata, hogy felvértezze a tanulásban lemaradó, alacsony teljesítményt felmutató, legtöbbször hátrányos helyzetü, elsősorban roma tanulókat a társadalmi tájékozódásra és beilleszkedésre, saját érdekeik védelmére.

A társadalom hierarchikus rétegzettsége miatt az iskolák azonban ma nem képesek felkínálni minden gyermeknek azokat a lehetőségeket, esélyeket, amelyek optimális kibontakozásukhoz szükségesek. A társadalomban van legalsó társadalmi csoport, és vannak olyan iskolák, ahová ennek a csoportnak a gyermekei járnak (Kertesi-Kézdi, 2016). A társadalom nyitottságának a legérzékenyebb mérőeszköze az, hogy milyen lehetőségeket képes biztosítani az ilyen gyerekek 
számára. Kertesi Gábor és Kézdi Gábor (2016) arra irányítják rá a figyelmet, hogy ma a szegregációból eredő hátrányok összhangban vannak az iskolaválasztás egyszerü modelljével, amely modell az iskolák érzékelt minőségének különbségeire, valamint a képességek és a családi háttér szerinti szelekcióra épül.

A szakemberek egyetértenek abban, hogy Magyarországon a hátrányos helyzetü, a tanulásban leszakadt gyerekek iskolán belüli problémája, lemaradásuk kompenzálása csak az oktatás gyökeres megváltoztatásával, reformjával érhető el, ezért keresni kell azokat a tanítási módszereket, amelyek minden társadalmi csoport gyermekei számára megfelelnek (Ostorics et al., 2016). Magyarországon több újszerü, alternatív pedagógiai módszert ismerünk, de, mint Radó Péter (1996) fogalmaz, ,a magyar pedagógiai gyakorlatban megszokott, a többséghez tartozó gyerekek oktatása során sokszor sikerrel alkalmazott pedagógiai módszerekkel a hátrányos helyzetủ tanulókat nehéz iskolai sikerhez juttatni”. Még ma is érvényes, miszerint a pedagógustársadalom nem készült fel arra, hogy heterogén tanulói csoportok számára megfelelő oktatást nyújtson, hogy képes legyen az iskolában a különböző szociális hátrányokkal érkező tanulóit olyan módon kezelni, hogy megfelelő ismeretekkel rendelkezzenek az iskolát körülvevő társadalomról és gazdaságról, és képes legyen az iskola és a munka világa között közvetíteni. Halász Gábor (2017) arra mutat rá, hogy a nevelés-oktatás folyamatában a tudásközvetítés mellett fontos azoknak az értékeknek és viselkedési mintáknak az átadása, amelyek magukban foglalják a normák és szabályok átadását, illetve alkalmazásuk megtanulását, és amelyek az egyént hozzásegítik a társadalmi életben és a gazdasági tevékenységben való részvételhez. Ma nem azt várjuk el többé az iskolától, hogy stabil munkahelyekre képezzen munkaerőt, hanem azt, hogy olyan egyéneket bocsásson ki, akik képesek fejlödni és alkalmazkodni a gyorsan változó világ igényeihez.

\section{A HAZAI OKTATÁS EREDMÉNYESSÉGE}

A McKinsey-jelentés (2007) szerint az oktatási rendszer sikerét elsősorban három tényező segíti. Az első és legfontosabb a pedagógusok tehetsége a nevelés és az oktatás együttes feladatát tekintve. A második, hogy a pedagógusok olyan tanítási módszereket alkalmazzanak, amelyek képesek a tanulók figyelmét lekötni, az érdeklődésüket felkelteni. A harmadik, hogy az oktatási rendszer képes legyen a családi háttérből adódó egyenlőtlenségeket mérsékelni, közelíteni.

A Programme for International Student Assessment (PISA ${ }^{1}$ ) nemzetközi felmérés szerint hazánkban az oktatás területén a fejlett országokhoz képest lema-

\footnotetext{
${ }^{1}$ Magyarországon 2000 óta háromévente tartanak mérést matematika, szövegértés és természettudományos területen a tizenöt évesek körében.
} 
radás tapasztalható. A tanulók tudását és teljesítményét meghatározó vizsgálatok azt jelzik, hogy nem a tanulók mennyiségi tudásával van a probléma, hanem a sokoldalú képességek fejlesztése és a tudás minősége az, amelyben lemaradtunk. ${ }^{2}$ Az eredményekből arra következtethetünk, hogy iskolai oktatásunk tartalma, módszerei és eszközei nem felelnek meg annak az értékrendnek és tudáskoncepciónak, amelyre az ebben a tekintetben eredményes országok iskolai oktatása épül (Ostorics et al., 2016). Fontosnak tartjuk megjegyezni, hogy a felmérés elsősorban nem a tanulók szereplésére, hanem a teljesítményükön keresztül az ország oktatási rendszerére fókuszál.

Probléma az egyenlötlen minőségeloszlás. Az elitiskolák teljesítménye kimagasló, míg a hátrányos helyzetű térségekben müködő iskolák messze elmaradnak az átlagtól. A mérések azt bizonyítják, hogy a szociális vagy családi háttér, vagyis az, hogy a gyermek milyen környezetből indul (család, helyi közösség, település, járás), Magyarországon 23,1 százalékban magyarázza az iskolai teljesítményt, míg az OECD- (Gazdasági Együttműködési és Fejlesztési Szervezet) országok átlagában ez az érték csak 14,8 százalék (OECD, PISA 2012). A PISA-felmérések alapján az egyes iskolák közötti különbségek is nagyok: míg az OECD átlagában 36 százalékot magyaráz az egyes diákok olvasási teljesítménykülönbségéből az iskola különbsége, addig nálunk ugyanez a magyarázóerő 71 százalék.

Szintén magasabb a nemzetközi átlagnál a településtípus szerinti teljesítménykülönbség az egyes képességterületeken. A magyar tanulók eredményeiben nagyjából négyszer nagyobb különbség mutatkozik a 3000 fő alatti települések és a százezer fő feletti város(ok), illetve Budapest között, mint az OECD átlagában. A tanulói eredmények tekintetében elmondható, hogy a magyar tanulók az OECD-átlag körül, de fokozatosan enyhe teljesítményromlást mutatnak fel

${ }^{2}$ A 2016. decemberi összegzés szerint Magyarország eredménye matematika, természettudomány és szövegértés területén lényegesen elmarad az OECD-országok átlagától. Ez azt is jelenti, hogy matematikából és természettudományból a tagországok leggyengébb negyedéhez, szövegértésböl a leggyengébb ötödéhez tartozunk. A vizsgálat során azt mérték, hogy az adott ország tanulói milyen mértékben képesek az elsajátított tudást a hétköznapi életben alkalmazni.

Egy másik oktatási teljesítményt értékelő nemzetközi szervezet, az International Association for the Evaluation of Educational Achievement (IEA) legújabb felmérése szerint a magyar általános iskolások mind a matematikában, mind a természettudományokban jobb teljesítményt nyújtanak az átlagnál. A vizsgálat során föleg azt mérték, hogy az adott ország tanulói milyen mértékü kognitív ismeretekkel rendelkeznek, vagyis hogy mennyire sajátították el az adott évfolyam tantervi követelményeit.

A TIMSS (Trends in International Mathematics and Science Study [Nemzetközi matematikaés természettudományi vizsgálat]) 2007-ben végzett nemzetközi összehasonlító felmérése a matematikai és természettudományos képességek felmérésére irányult a 4. és 8. osztályosok körében. Az ötvenkilenc országban zajló vizsgálat során a magyar tanulók jobban teljesítettek a résztvevők átlagánál, és a kiválóan teljesítők aránya alapján az élvonalban végeztek, habár az 1995-ös első méréshez képest tapasztalható némi visszaesés a teljesítményben. 
a matematikai és természettudományos feladatok megoldásában (2000, 2003, 2009, 2012, 2015). A szövegértési eredményekben 2009-ben enyhe javulás, majd 2015-ben gyengülés következett be a többi terület megközelítő stagnálása mellett (Steklács, 2018). Az OKÉV-mérés (Országos Közoktatási és Értékelési Vizsgaközpont) szerint nagy az eltérés a hátrányos és a nem hátrányos helyzetű tanulók szövegértési és matematikai teljesítménye között. A többségben hátrányos és halmozottan hátrányos helyzetü tanulókat nevelö-oktató iskolák eredményei jelentős elmaradást mutatnak az országos átlagtól.

A lemaradást társadalmi okok magyarázzák. Legnagyobb fogyatékosságaink az iskolák közötti különbségek, illetve a gyerekek családi háttere, amely jelentősen befolyásolja az iskolában nyújtott teljesítményt. Az erősen differenciáló és szelektáló magyar rendszer jellemzője, hogy a már meglévő társadalmi hátrányokat a gyermekek között nem csökkenti, hanem átörökíti. Emiatt a nevelési-oktatási folyamatban az integráció, amely a különböző nevelést igénylő gyerekek együttnevelését, oktatását takarja, egyre jelentősebb szerepet játszik. Fejes József Balázs $(2018,115$. szerint a problémát súlyosbítja, hogy „,a pedagógusokra alig számíthatunk abban, hogy az integrációs folyamatok fontosságát a közvélemény felé közvetítsék".

A magyar oktatásról általános vélekedés, hogy a színvonala, eredményessége nem kielégítő, időben hanyatló, gyengesége és megalapozatlansága pedig már az ezredfordulón megmutatkozott. A társadalom és az oktatás szereplöi folyamatosan vészjeleket adnak le, amelyek arról szólnak, hogy szétszakadóban van a rendszer, romlik a tanulók teljesítménye, és egyre szélesebb a gyenge eredményeket felmutatók köre. Ez a tény ennek a csoportnak a nevelésére, oktatására irányítja rá a figyelmet.

\section{AZ OKTATÁSI RENDSZER ALULTELJESÍTÉSÉNEK ÉS EGYENLŐTLENSÉGEINEK OKAI}

A hazai oktatási rendszer gyenge eredménye és lemaradása arra késztet minket, hogy rámutassunk az előidéző okokra (György, 2012). Elsőként említjük a szabad iskolaválasztást és az ennek eredményeként létrejött egyenlötlenséget. A szabad iskolaválasztás, az egyenlőtlenség és a gyenge eredmények között szoros összefüggés mutatható ki. Az egyik kiváltó ok a 80 -as évek közepétől érvényben lévő szabad iskolaválasztás lehetősége, amelynek eredménye az lett, hogy a tehetösebb szülők jobb minőségű iskolákba járatják gyerekeiket, elsősorban oda, ahol a hátrányos helyzetüek, különösen a roma gyerekek aránya alacsony, elenyésző. Szakmai konszenzus mutatkozik abban a tekintetben, hogy ezt a szabadságot felszámolni visszalépés lenne. Megoldás mégis van, találunk olyan települést Magyarországon, ahol a természetesen végbemenő gettósodás és szegregáció következményeit a hátrányos helyzetü, elsősorban roma tanulók arányos elosztásával kívánják orvosolni (például Hódmezővásárhely). 
A másik egyenlőtlenséget erősítő ok föképp anyagi és rendszerszervezési (tanügyigazgatási) természetű. A köznevelési rendszer 2013-as átalakítását megelőző szabályozás értelmében az iskolák finanszírozását 80 százalékban az állam vállalta magára, a fennmaradó 20 százalékot a fenntartónak (többségében önkormányzatoknak) kellett előteremtenie. A központi források a 2002-2010 közötti időszakban 80 százalékról fokozatosan 50 százalék körüli arányra csökkentek. Az intézmények fenntartásához szükséges fennmaradó 50 százalékot a helyi önkormányzatoknak, a fenntartóknak kellett előteremteniük, miközben a kiegészítő normatívák erre nem teremtettek elegendő fedezetet a hátrányos helyzetben lévő helyi önkormányzatok számára. A magyar közoktatási rendszeren belüli egyenlőtlen erőforrás szétosztása nem tette lehetővé az esélyegyenlőség biztosítását, és véleményünk szerint az esetben sem tenné lehetővé, amennyiben sikerülne visszaállítani a 80 százalékos központi finanszírozási szintet, és visszaadnák az iskolákat a finanszírozásukra képes önkormányzatoknak. Az ok meglehetősen egyértelmü: vannak olyan önkormányzatok, amelyeknek nincsenek saját bevételeik, míg a tehetős környékek iskolái a kielégítő önkormányzati finanszírozás mellett alapítványokba tudják gyüjteni a szülői hozzájárulásokat - igazságtalan és egyenlötlen helyzetet teremtve.

A hátrányos, halmozottan hátrányos helyzetü, jelentős mértékben roma tanulókat nevelő iskolák, tanulói összetételük miatt maguk állítják elő azt a helyzetet, amikor a pedagógusok megfelelő eszköz, módszer, ösztönzőerő hiányában elhagyják az iskolát. Emiatt egyrészt egyes térségekben pedagógushiány lép fel, másrészt magas lesz az utazó tanárok aránya, mivel az iskola nem képes „kitermelni" a szakos (például informatika, fizika, biológia, kémia) pedagógusait. Ezért szükség van egy olyan forráselosztási rendszerre, amely a hátrányos helyzetü térségeknek többet juttat, és mérsékli az egyenlőtlenségeket. A Klebelsberg Központ törekvése ennek az egyenlőtlenségnek a felszámolása kell hogy legyen.

Harmadsorban, szoros összefüggés mutatható ki a pedagógusok munkája és teljesítménye között. Varga Júlia már 2008-as tanulmányában arra hívta fel a figyelmet, hogy a pedagógus pályára az alacsony presztízs és bérezés miatt háromszoros kontraszelekció a jellemző. Először is, a tanárképző intézményekben az alacsony felvételi pontszám (volt) a jellemzö, amely azt feltételezi, hogy nem csak a legtehetségesebb diákok kerülnek kiválasztásra. Voltak olyan évek, amikor egyes reálszakokra (például: kémia, biológia, fizika) rendkívül gyenge érettségi eredménnyel is be lehetett kerülni. További összefüggés, hogy magas azoknak a száma, akik a diploma megszerzése után azért mennek el tanítani, mert nem találnak jövedelmezőbb állást maguknak.

A köznevelés feladata, hogy a magyar oktatás 1990 óta mélyülő problémáit, gyengeségeit, eredménytelenségét orvosolja. A továbbiakban a szabad iskolaválasztáshoz és ennek eredményeként az egyenlőtlenségek létrejöttéhez is kapcsolódó szegregáció kérdésével foglalkozunk. 


\section{A HÁTRÁNYOS HELYZETŰ, ELSŐSORBAN ROMA GYEREKEK A HAZAI ISKOLÁKBAN}

Ma a magyar iskolákban a szülők iskolai végzettségének szinte automatikus leképződése jelenti az egyik fö veszélyt (Kozma, 1998). A családi háttér mint egy sokdimenziós egyenlötlenségi tér ragadható meg, amelyet befolyásol a szülők társadalmi pozíciója, a család kulturális státusza, a kultúra közvetítőinek igénybevétele, a szülők anyagi helyzete és a család lakóhelye. A hátrányos helyzetü - legtöbbször a cigány etnikumhoz tartozó - gyerekek iskolai sikertelensége gyakran a hátrányos szociokulturális háttérrel - kulturális különbözőséggel, az iskolába lépés előtti lemaradással, hátránnyal - és a nyelvi kifejezőkészség hiányával magyarázható. Míg az értelmiségi környezetből induló gyerekek észrevétlenül „feltöltődnek” az iskolára, az iskola nyelvezete nekik szól, addig azok a gyerekek, akik nem birtokolják az iskola nyelvét és az iskolai környezet kódjait, lemaradnak, és kicsi lesz annak a valószínúsége, hogy az iskola világában otthonosan mozogjanak. A fó veszélyt az jelenti, hogy e rétegspecifikus hátrányok az iskoláztatási idő alatt állandósulhatnak, rögzülhetnek, az iskolából leszakadóknak a mobilitásra esélyük sincs, márpedig az egyének közt kialakult hierarchia határozza meg az életutat. A hierarchikus sorrend megváltoztatása, a pozíciók kiharcolása az egyén feladata, amely végső soron a felemelkedés, a mobilitás záloga (K. Nagy, 2015).

Az iskolai élet, amely a társadalmi élet leegyszerüsített változata, fokozatosan a családi életből nő ki, ezért az iskola feladata, hogy a családi háttérből eredő hátrányokat kompenzálja, és olyan pedagógiai eszközöket alkalmazzon, amelyek képesek arra, hogy az esélyek egyenlővé váljanak, a gyerekek közötti különbségek csökkenjenek, és mindenkinek ugyanolyan lehetősége legyen jövőjének felépítésére. A hátrányos helyzetü, elsősorban roma tanulókat gyakran a „problémás" jelzővel illetik, legtöbbször nyelvi kifejezőkészségük szegénysége miatt. A leggyakoribb ok, ami miatt a hátrányos helyzetű és roma gyerekek sikertelenek az iskolában, a nyelvi lemaradás, a szegényes szókincs, ami miatt az iskolában a közösség nem fogadja el őket, kirekesztődnek, peremre szorulnak. Emiatt a hátrányos helyzetü tanulók felzárkóztatásának még ma is egyik legfontosabb célja, hogy „oktatható” állapotba hozza őket.

A szociális kirekesztődés megakadályozása egy olyan átfogó nevelési, szocializációs programmal érhető el, amely a tanulót és tevékenységrendszerének a fejlesztését helyezi a középpontba. Úgy véli, hogy szocializációjuk csak akkor lehet sikeres, ha életkörülményeik, személyiségük, eddigi életútjuk ismeretében személyre szabott oktatási és nevelési program készül számukra. A hátrányos helyzetű tanulók folyamatosan emelkedő aránya iskolai nevelésükre-oktatásukra irányítja a figyelmet. Eredmények felmutatásához azonban az oktatás reformjára van szükség (Radó, 2016). A pedagógusoknak széles körü módszertani repertoár- 
ral, a képességekre, különbségekre figyelö, egyénre szabott pedagógiai eszközök és oktatási mérőrendszerek ismeretével kell rendelkezniük. A felzárkóztatás feladata olyan oktatás szervezése, amelynek a tudás átadásán kívül célja a szociokulturális lemaradás csökkentése.

\section{INTÉZMÉNYI SZEGREGÁCIÓ A HAZAI ISKOLÁKBAN}

Az intézményi szegregáció rendkívül változatos formában ölt testet a mai magyar oktatási rendszerben. Elsőként említjük, hogy a többiskolás településeken kialakulhat az iskolák közötti szegregáció, amikor is egy-egy intézmény, a nem roma szülők elvándorlása miatt roma és hátrányos helyzetü gyermekek által dominált intézménnyé válik.

A Klebelsberg Iskolafenntartó Központ, majd a Klebelsberg Központ megalakulása előtt az iskolákon belüli szegregáció az oktatásban bevezetett, tanulónként járó normatív támogatás okán is kialakulhatott, amely állapot jelenleg is fennáll. Az iskolák abban voltak érdekeltek, hogy tanulói létszámukat megtartsák, és sok diákot vonzzanak az intézménybe. Így a nem roma gyermekek „elvándorlásának” - ami általában a roma diákok egyre növekvő aránya miatt következik be - megakadályozása érdekében egyes iskolák szegregált osztályokat indítottak a roma diákok számára. Jelenleg is számos, sőt jelentős számú olyan iskola müködik, ahol a roma és nem roma gyerekeket elkülönítve tanítják. A roma gyerekeket befogadó szegregált osztályok az esetek legnagyobb részében különálló és rosszabb minőségủ épületekben, épületszárnyban találhatóak.

A szegregáció egyik formája a speciális iskolák, illetve speciális osztályok, amelyek a gyakorlatban azt jelentik, hogy a diákok alacsonyabb szintủ elvárásnak kell, hogy megfeleljenek, alacsonyabb színvonalú oktatásban részesülnek, és szükített tananyagot tanulnak. A speciális iskolákban jellemzően rendkívül magas a roma diákok aránya.

Az iskolalátogatás alóli felmentéssel megvalósított szegregáció a roma gyermekek elkülönítésének viszonylag általános módja. 2019-ig számos, különösen az évfolyamához képest túlkoros roma gyermeket magántanulónak nyilváníthattak, amelynek egyenes következménye, hogy az alapfokú oktatásból kikerülve, szakképzés hiányában, esélyt sem kapnak a munkaerőpiacon való megjelenésre. Ez évtől, azaz 2019-től ebben a tekintetben jogszabályi változás következett be. Iskolalátogatás alóli felmentés esetén egyéni tanulói munkarend akkor kérelmezhető, ha azt a tanuló egyéni adottsága, sajátos helyzete indokolja, és a tanuló fejlődése, tanulmányainak eredményes folytatása és befejezése szempontjából előnyös. Az engedélyt meghatározott időre kapja a tanuló. Az egyéni munkarendben tanulók felmentést kapnak a kötelező tanórai foglalkozások alól, a tantárgyakból azonban osztályozó vizsgát kell tenniük. A magántanulói státusz tekintetében 
mostantól az Oktatási Hivatalnál $(\mathrm{OH})$ kell kérvényezni az egyéni tanulói munkarendet, amely a korábbi magántanulói jogviszonynak felel meg (URL1).

Az Eötvös József Program keretében a Balogh Gyula vezette munkacsoport (Balogh et al., 2015) megvizsgálta a hazai szegregált helyzetű iskolák fejlesztésének lehetőségeit. Ök a szegregálódás irányát a következőkben határozzák meg: szétválási (a középosztály migrációja), tudatos elkülönítési (állami, kormányzati, fenntartói intézkedések) és spontán kialakult elkülönülési folyamat (zárványtelepülések) eredménye, és ezek kombinációja. Úgy vélik, hogy „a magyarországi szegregációval kapcsolatosan megállapítható, hogy ún. szegregációs kulcsintézmények mindenkori, helyi aktuális állapota, sajátosságai befolyásolják a folyamatokat. Ezen kulcsszereplök között meghatározhatunk elsődleges szereplőket (szegregációs konstruktum, elitkomplexum, elkülönülő komplexum, zárvány), másodlagos szereplőket (kisebbségi oktatást megvalósító intézmények, sajátos nevelési igényü [SNI] tanulókat befogadó intézmények, tehetséggondozó intézmények) és ún. befolyásoló szereplőket (értékek, felvetések, hiedelmek, attitüdök, érzések)."

\section{EGY JÓ PÉLDA A HÁTRÁNYOS HELYZETÚ, ELSŐSORBAN ROMA TANULÓK INTEGRÁCIÓJÁNAK A MEGVALÓSÍTÁSÁRA}

A hejőkeresztúri iskolában használt, a Stanford Egyetemről adaptált, majd továbbfejlesztett Komplex Instrukciós Program (KIP) a tudásban és szocializáltságban heterogén tanulócsoportok nevelésére, oktatására alkalmas metódus. A KIP alkalmazása egyrészt segíti a hátrányos helyzetủ, tanulásban lemaradt tanulók felzárkóztatását, másrészt, a csoportfoglalkozások során a heterogén összetételü osztályokban a speciális (státuszkezelő) instrukciós eljárás alkalmazásán keresztül lehetőség nyílik a tanulóknak az együttműködési szabályokra történő felkészítésére, a rejtett tehetségek kibontakoztatására a sokféle, eltérő képességet megmozgató tananyag alkalmazásán keresztül. A feladatok összetettsége minden tanulónak felkínálja a feladatokhoz való hozzáférést és intellektuális kompetenciájának a felvillantását, amelyen keresztül a különböző szociális háttérrel, tudással rendelkező gyerekeknek is alkalmuk nyílik a feladatok sikeres véghezvitelére, megoldására. A KIP lehetőséget ad a pedagógusnak arra, hogy a feladatok megfelelő végrehajtása érdekében megtanítsa a gyerekeket a csoporton belüli együttmüködési szabályokra, a meghatározott szerepek elsajátítására. A pedagógusnak az óra során alkalma nyílik a csoport egésze és a csoporttagok egyedi munkájának a folyamatos követésére. A KIP-et megalapozó elméletek közül a tudáshoz való egyenlő hozzáférést, a tanulók között kialakult rangsort meghatározó tényezőket és a tanulói heterogenitás kezeléséről vallott nézeteket tartjuk a program szempontjából legfontosabb ismérveknek. 


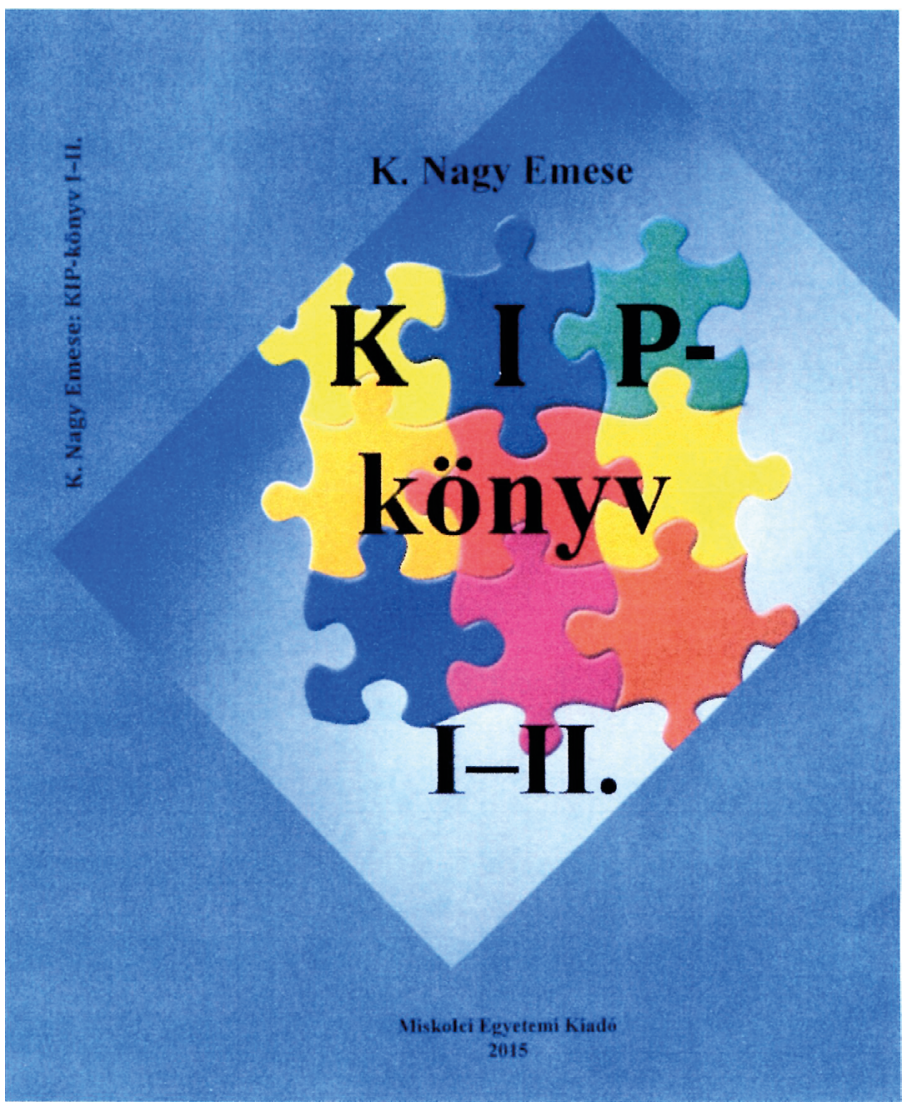

1. ábra. A Komplex Instrukciós Program (KIP) olyan speciális kooperatív tanítási eljárás, amely lehetővé teszi a tanárok számára a magas szintű csoportmunka szervezését olyan osztályokban, ahol a tanulók közötti tudásbeli különbség és kifejezökészség tág határok között mozog, és az osztályban végzett munka eredményeként a hátrányos helyzetű tanulók leszakadását lassítja vagy megakadályozza

\section{ÖSSZEGZŐ GONDOLATOK}

Írásunk arra irányítja rá a figyelmet, hogy a jelenlegi iskolarendszer erős szegregációs folyamatokat generál. A roma tanulók iskolai problémájának megoldásával kapcsolatban egyre inkább egyértelművé válik, hogy a szegregációt csak jogszabályi beavatkozással lehet felszámolni, amelynek azonban nagyok a politikai kockázatai és költségei. Éppen ezért ennek lehet a következménye az, hogy a szabad iskolaválasztás elvének a megszüntetése egyik kormányzat esetében sem merült fel addig komolyan. Ebben a pillanatban megoldást jelenthetne, kihasználva a centralizált rendszert, egy deszegregációs stratégia kidolgozása és monitorozása. 
Újra szükséges átgondolni a hat- és nyolcosztályos, valamint az egyházi iskolák mint szegregáló és a jó családi háttérből származó gyerekek gyüjtőhelyeként aposztrofálható intézmények szerepét és hatását.

\section{IRODALOM}

Balogh Gy. - Zelinváry B. - Mayer J. et al. (2015): Az oktatási szegregáció formáinak szervezeti kultúra központú megközelitése a megyei jogú városokban. Eötvös József program

Cohen, G. E. - Lotan, A. R. (2014): Designing Groupwork Strategies for Heterogeneous Classrooms. New York-London: Teachers College, Columbia University

Fejes J. B. (2018): A deszegregációval kapcsolatos vélemények befolyásolási lehetőségei pedagógusok körében In: Fejes J. B. - Szűcs N. (szerk.): Én vétkem. Helyzetkép az oktatási szegregációról. Szeged: Motivációs Oktatási Egyesület, 115. https://mek.oszk.hu/18200/18263/18263.pdf

György L. (2012): Oktatáspolitikai kihívások. Magyarország vs. Szingapúr. Doktori értekezés. Budapest: BME Gazdaság és Társadalomtudomány Kar Gazdálkodás- és Szervezéstudományi Doktori Iskola

Halász G. (2017): Az oktatási rendszer. http://halaszg.ofi.hu/download/Oktatasi\%20rendszer\%20 -\%20HTML.htm (letöltve 2017. 01. 28.)

K. Nagy E. (2015): KIP Könyv I-II. [Miskolc] Miskolci Egyetemi Kiadó, http://kipkozpont. uni-miskolc.hu/content/cont_57077254534252.71481005/kip-konyv.pdf

K. Nagy E. (2018): Differenciált Fejlesztés Heterogén Tanulócsoportban (DFHT) tanitási-tanulási stratégia. Eger: Líceum Kiadó, http://publikacio.uni-eszterhazy.hu/3405/1/Differenci\%C3\%A1lt\%20fejleszt\%C3\%A9s.pdf

Kertesi G. - Kézdi G. (2016): Iskolai szegregáció, szabad iskolaválasztás és helyi oktatáspolitika 100 magyar városban. http://beszelo.c3.hu/onlinecikk/iskolai-szegregacio-szabad-iskolavalasztas-es-helyi-oktataspolitika-100-magyar-varosban

Kozma T. (1998): Társadalmi egyenlőtlenségek az iskolában. In: Závodszky G. - Halász G. - Báthory Z. et al.: Tanulmányok a közoktatásról. OM-OKNT 131-146.

McKinsey Report (2007): How the World's Best-Performing School Systems Come out on Top. http://alamin99.wordpress.com/2008/02/22/mckinsey-report/

Ostorics L. - Szalay B. - Szepesi I. et al. (2016): PISA összefoglaló jelentés 2016. Budapest: Oktatási Hivatal

Radó P. (1996): Jelentés a magyarországi cigány tanulók oktatásáról. Budapest: Oktatáskutató Intézet

Radó P. (2016): A csúfos PISA-bukás oka az oktatás minöségének súlyos romlása. hvg.hu, http:// hvg.hu/itthon/20161206_PISA_2015_meredek_lejton_a_magyar_kozoktatas_rado_peter (letöltve 2017. 02. 03.)

Steklács J. (2018): PISA 2015 után, PISA 2018 előtt. A szövegértő olvasás fejlesztésének, tanításának feladatai. Könyv és Nevelés, 1, http://folyoiratok.ofi.hu/konyv-es-neveles/pisa-2015-utanpisa-2018-elott

Varga J. (2008): Az iskolaügy intézményrendszere, finanszírozása. In: Fazekas K. - Köllő K. Varga J.: Zöld Könyv a magyar közoktatás megújitásáért. Budapest: ECOSTAT, 235-258. https://mek.oszk.hu/08200/08222/08222.pdf

URL1: https://eduline.hu/kozoktatas/20190902_egyeni_tanuloi_munkarend_tudnivalok (letöltve 2019. 09. 09.) 